УДК 332

Волощук Н.Ю., к.е.н., доцент

Карпатського інституту підприємництва

\title{
ІННОВАЦІЙНІСТЬ РЕГІОНАЛЬНОГО РОЗВИТКУ СФЕРИ ТУРИЗМУ
}

У статті розглянуто особливості забезпечення регіонального розвитку сфери туризму на інноваційній основі. З'ясовано унікальність географічного розташування Закарпатської області, що безпосередньо впливає на розвиток туристичної індустрії краю, оскільки регіон межує з чотирма країнамичленами Євросоюзу. Дослідженням виявлено, що вагомою складовою розвитку туризму на території Хустського району $є$ розроблені програми сімейного відпочинку, що нині набувають особливої актуальності, оскільки дають можливість відпочинку з дітьми. Окреслено інноваційність спрямування розвитку сфери туризму як на національному, так і регіональному рівнях, що передусім зумовлюється: впровадженням сучасних інформаційних технологій для підтримки інноваційної діяльності та новаційних методів ведення бізнесу, розробленням особливих систем роботи готельно-ресторанних об'єктів, які сприяють розширенню їх функціональних послуг, зокрема задіяння мультимедійних технологій у вигляді різноаспектних довідників, рекламних буклетів, електронних каталогів інноваційних пропозицій, в тому числі й в мережі Інтернет.

Ключові слова: інноваційні підходи, сфера туризму, регіональний розвиток, інформаційні технології, туристичні програми, зелений туризм, організаційно-управлінська діяльність.

Волощук Н.Ю.

\section{ИННОВАЦИОННОСТЬ РЕГИОНАЛЬНОГО РАЗВИТИЯ СФЕРЫ ТУРИЗМА}

В статье рассмотрены особенности обеспечения регионального развития сферы туризма на инновационной основе. Выяснено уникальность географического положения Закарпатской области, непосредственно влияет на развитие туристической индустрии края, поскольку регион граничит с четырьмя странами-членами Евросоюза. Исследованием установлено, что важной составляющей развития туризма на территории Хустского района являются разработанные программы семейного отдыха, сейчас приобретают особую актуальность, поскольку дают возможность отдыха с детьми. Определены инновационность направления развития сферы туризма как на национальном, так и региональном уровнях, прежде всего обусловлено: внедрением современных информационных технологий для поддержки инновационной деятельности и новационных методов ведения бизнеса, разработкой особых систем работы гостинично-ресторанных объектов, которые способствуют расширению их функциональных услуг , в частности задействования мультимедийных технологий в виде разноаспектных справочников, рекламных буклетов, электронных каталогов инновационных предложений, в том числе и в сети Интернет.

Ключевые слова: инновационные подходы, сфера туризма, региональное развитие, информационные технологии, туристические программы, зеленый туризм, организационноуправленческая деятельность.

Voloshchuk N.Yu.

\section{THE INNOVATIVENESS OF REGIONAL DEVELOPMENT OF TOURISM}

The article discusses the features of regional tourism development based on innovation. Clarified the uniqueness of the geographical location of Transcarpathian region, which directly affects the development of the tourism industry of the region, as the region borders on four member countries of the European Union. The study identified that an important component of tourism development on the territory of Khust district developed program family holiday at present are of particular relevance, as they enable families with children. Outlined the innovative directions of development of tourism at both national and regional levels, first due to: the introduction of modern information technologies to support innovative activities and innovative methods of doing business, development of special systems for hotel and restaurant facilities that enhance their functional features, in particular the utilization of multimedia technologies in the form of multidimensional guides, promotional brochures, electronic catalogues of innovative proposals, including on the Internet.

Key words: innovation, tourism, regional development, information technologies, tourism programs, ecotourism, organizational and managerial activities.Постановка проблеми у загальному вигляді і їі зв'язок 3 важливими науковими та практичними завданнями.

Баготоаспектність розвитку сфери туризму у сучасному світовому вимірі набуває 
вагомого значення, оскільки виступає пріоритетною галуззю рекреаційно-туристичної індустрії. Поєднання інтересів різновидів рекреаційної діяльності, формує синергічний, мультиплікаційний ефект у досягненні результатів, передусім задоволенні потреб суспільства в організації відпочинку і дозвілля. Зазначений процес супроводжується перманентністю впровадження інноваційних підходів, що сприяє перспективам розвитку туристичної сфери.

Аналіз останніх досліджень і публікацій, у яких започатковано вирішення проблеми. Дослідженню регіональних особливостей розвитку сфери туризму, формування інноваційного середовища в межах функціонування туристичної індустрії, в тому числі у напрямі виявлення природно-ресурсного і туристично-рекреаційного потенціалу місцевості, формування рекреаційної політики, розроблення туристичних проектів і програм присвячено наукові праці відомих українських вчених, серед яких Б. Данилишин, С. Дорогунцов, В. Міщенко, Я. Коваль, О. Новоторов, М. Паламарчук [1], В. Кравців, В. Свдокименко, М. Габрель [2], О. Любіцева [3] та ін. Зважаючи на значний науково-теоретичний і практичний доробок в дослідженні сфери туризму, окремих розвідок потребують регіональні перспективи його зростання.

Метою статті $є$ виокремлення пріоритетів розвитку сфери туризму в межах окремого рекреаційно-туристичного району, зокрема Хустського.

Виклад основного матеріалу дослідження 3 повним обгрунтуванням отриманих наукових результатів. Вагомою складовою забезпечення збалансованого регіонального розвитку $\epsilon$ ефективне функціонування пріоритетних сфер i видів економічної діяльності. До зазначених пріоритетів відноситься сфера рекреації і туризму в межах Закарпатської області, давно відомого курортного і рекреаційно-туристичного центру України.

Регіон є унікальною екологічною системою Заходу України з різноманітним рельєфом та кліматичними умовами. Його територія на півночі захищена Карпатським хребтом, з північного заходу - Татрами, з півдня - західними Румунськими горами i Мараморошським масивом. Від інших регіонів країни регіон відділяють Яблонецький, Вишківський, Ужоцький, Верецький та Воловецький перевали висотою від 931 м до 1614 м над рівнем моря. Близько 80\% території краю займають гори, серед яких найвища точка України - гора Говерла (2061 м). Територія області перерізана густою мережею рік. Середня густина річкової сітки $-1,7$ км/км 2 . Усього територією області протікає 9426 рік, сумарною довжиною 19723 км. Загальна довжина 155-ти рік, кожна 3 яких довша 10-ти км, становить 3,43 тис. км. 3 них, ріки Тиса, Боржава, Латориця та Уж мають довжину більше 100 км кожна. Загальна протяжність річки Тиса 967 км, з них в межах України - 262 км. На території області вона приймає праві притоки: річки Косовська, Тересва, Теребля, Ріка, Боржава. На території області наявні 698 водних об“єктів в т.ч. 9 водосховищ комплексного призначення, 645 ставків, 44 озера. Найбільшим $\epsilon$ Синевирське озеро 3 площею близько 7 га, середньою глибиною 15-16 м. Воно розташоване на висоті 989 м над рівнем моря [3, с. 9]. Водночас розвитку туризму і рекреації сприяє м'який помірно-континентальний клімат, мальовничі ландшафтні краєвиди, наявність термальних і мінеральних вод, культурні багатовікові традиції краю формуючи унікальність туристичного середовища і приваблюючи як вітчизняних, так i зарубіжних туристів. Крім цього, потрібно відмітити унікальність геостратегічного розмічення регіону, який знаходиться на перетині європейських транспортних магістралей, близькістю кордонів з країнами-членами Свросоюзу.

Відмічена багатоаспектність факторів впливу на забезпечення розвитку сфери туризму дає можливість його результативного зростання.

В регіональному вимір перспективи розвитку отримали як туристичні об'єкти, так і багатогранні види рекреаційного туризму. Так, мережа туристично-рекреаційних 
об'єктів регіону поєднує понад 170 од., 3 них 60 санаторно-курортних закладів та 44 турбаз, 14 баз відпочинку, які готові до одночасного прийому понад 15 тис. відпочиваючих. У 2017 р. суб’єктами туристичної діяльності (туристичними організаціями) обслужено 31,3 тис. осіб, ними надано 100,8 тис. туроднів, операційні витрати на надання туристичних послуг становили 11380,9 тис. грн., майже удвічі більше, ніж у 2015 р. (6586,2 тис. грн.), дохід від наданих туристичних послуг становив 16701,3 тис. грн. (а в 2015 р. - 9441,4 тис. грн.) [8, с. 174, 185].

Вагоме значення для розвитку туристичної сфери має Хустщина. Вона $€$ перлиною і центром української Мараморощини на Закарпатті. На території району розташовано 30 об'єктів туристично-рекреаційного, санаторно-курортного, оздоровчого призначення та готельних господарств (3 них 20 працюючих), що дозволяє одночасно розмістити до 2 тисяч осіб. Близько 100 садиб у сфері сільського зеленого туризму, що дозволяє розмістити близько 300 осіб.

Активізація просування місцевих туристичних $\mathrm{i}$ курортних послуг на туристичних ринках області і Хустського району відбувається за сприяння суб'єктів туристичної діяльності, які беруть безпосередню участь у міжнародних туристичних виставках і ярмарках. Нещодавно підписано угоду про співпрацю з містом Сату-маре, Румунія, щодо обміну фолькльорними колективами, колективами народної творчості, туристами. Щорічно проводиться Міжнародний фестиваль "Пинтя-фест - фатьовий фестиваль для всіх варятів", с. Велятино (серпень місяць). На базі туристичного комплексу "Теплі води" (термальні басейни), с. Велятино, створений та діє турінфоцентр, якому, за сприяння обласної програми з туризму, передано техніку та інвентар, сувенірну і презентаційну продукцію. Аналогічний ТІЦ планується для відкриття в курортній зоні с. Шаян. Розглядається можливість, 3 допомогою департаменту економічного розвитку і торгівлі Закарпатської облдержадміністрації, облаштування туристично-інформаційного центру в фойє адмінбудинку Хустської райради, як комунальне підприємство Хустської райради, або підрозділ сектору туризму Хустської РДА. Виготовлений туристичний промо-ролик "Туристична Хустщина запрошує" та відеоматеріал про туристичні можливості Хустщини [7].

Доцільно відмітити, що за кошти програми розвитку туризму та курортів в Закарпатській області виготовлено та передано селищній та сільським бібліотекам 32 вивіски - міжнародної позначки туристично-інформаційних центрів - літери „і“ та 435 книг про туристичні можливості області для облаштування туристичних інформаційних офісів при бібліотеках; паспортизовано та промарковано туристичний маршрут „Шлях Пинті"; виготовлені рекламні буклети про туристичні можливості району; виготовлено 5 туристичних придорожніх знаків типу 5.53 [6]. У процесі функціонування сфери туризму здійснено інвентаризацію суб'єктів туристичної індустрії краю, здійснено аудиторське оцінювання можливих туристичних територій, що дадуть змогу розширити привабливі території для зацікавлення туристів і рекреантів. При цьому, узагальнено туристичні атракції та можливі місця відпочинку з виявленням туристичних принад населених пунктів Хустщини.

3 метою поповнення низки організаційно-інноваційних підходів до забезпечення розвитку сфери туризму ДП „Хустське лісодослідне господарство” [2], облаштовано рекреаційні стоянки на березі Вільшанського водосховища та на правій стороні автодороги Р-21 Долина-Хуст, між населеними пунктами Противень та Н. Бистрий, нижче ТРГЕС та місця відпочинку в с. Монастирець, Медвежий, Н. Бистрий на землях лісового господарства. 3 цією ж метою встановлено туристичні придорожні знаки типу 5.53 та надано пропозиції департаменту економічного розвитку і торгівлі Закарпатської облдержадміністрації щодо необхідності встановлення інших інформаційно-вказівних 
знаків типу 5.53, що вказують на місце знаходження історико-культурних та туристичних об'єктів. Також встановлено близько 20 інформаційних знаків до об'єктів туристичної інфраструктури силами власників цих об'єктів.

Дослідженням виявлено, що вагомою складовою розвитку туризму на території Хустського району є розроблені програми сімейного відпочинку, що нині набувають особливої актуальності, оскільки дають можливість відпочинку з дітьми. 3 цією метою було розроблено низка різноспрямованих екскурсійних туристичних програм, зокрема „Найцікавіші місця Хустського району”, „Найсмачніші місця Хустського району” тощо. Водночас, в межах досліджуваного району успішно функціонують паспортизовані туристичні маршрути „Шлях Пинті”, три 3 туристичні маршрути в с. Широкий, зокрема присілок Гонцош - г. Кичера - пол. Фріяль - г. Водиця - пол. Палений - г. Скала Нижній Бистрий, промарковані FORZA, а також сплав на надувних плотах, човнах, катамаранах і байдарках „По гірській Тисі”, походи до гірських вершин і ознайомлення 3 мальовничими ландшафтними територіями. Крім цього, нещодавно розроблено туристичний бренд Хустщини, який було затверджено на районному рівні.

3 метою реалізації, співфінансування міжнародних та національних проектів, програм, грантів за сприяння сектору підготовлено проекти до Державного фонду регіонального розвитку, який може реалізуватися за рахунок коштів державного бюджету, отриманих від Європейського Союзу [7]:

- „Ресурсний центр розвитку туризму” - Центр мережі сталого і всебічного розвитку сільських громад в транскордонному просторі»;

- „Облаштування зони відпочинку на березі водосховища Теребле-Ріцької ГЕС” в с. Вільшани Хустського району";

- Туристичний комплекс для сімейного відпочинку з форелевим господарством „Ізаліс".

Доцільно відмітити, що для розвитку туристичного комплексу у напрямі сімейного відпочинку в межах форелевого господарства „Ізаліс”, районною радою було профінансовано зазначений проект в сумі 4300 тис. грн. із залученням 500 тис. грн. співфінансування за рахунок місцевого бюджету Ізи та 150 тис. грн. для виготовлення проектно-кошторисної документації комплексу.

В цілому, розвиток туризму відіграє важливу роль у підвищенні рівня добробуту і благополуччя мешканців краю, оскільки сприяє само зайнятості населення, зниженню рівня безробіття, формуванню нових робочих місць і отримання додаткових заробітків. Керівництво району постійно впроваджують пілотні туристичні проекти, зокрема у 2018 р. було реалізовано проект „Про пілотний проект з розвитку сільського туризму Хустського району у 2018 році", що дало успішні результати.

Таким чином, інноваційні підходи до забезпечення розвитку туристичної сфери Хустського району Закарпатської області, передусім стосуються [9]: створення інформаційно-туристичного центру, туристичної ради рішення якої є обов'язковим для розгляду владою, підготовка п'ятнадцяти туристичних гідів, приєднання до програми транскордонного співробітництва, залучення до управління розвитком туристичної галузі творчих і креативних фахівців, що вміють працювати в умовах змінності ситуацій, і необхідності прийняття виважених управлінських рішень на інноваційній основі. Водночас, систематичним $є$ проведення різного роду інноваційно спрямованих семінарів 3 навчанням щодо популяризації розвитку агро-, екологічного і сільського зеленого туризму. В межах зазначених семінарів обговорюються реальні кроки та шляхи зміцнення відмічених видів туризму.

Особлива увага в Закарпатті й Хустському районі приділяється саме розвитку зеленого туризму як найбільш доступного для більшості споживачів туристичних послуг. Різноплановість зазначеного туризму може стосуватися як пізнавальних аспектів 
сприйняття різноманітності видів, зокрема вивчення і збирання лікарських трав, грибів, ягід, риболовлі, так і лікарських з наданням послуг масажу, фіто- і аромотерапії тощо.

Інноваційність спрямування розвитку сфери туризму як на національному, так i регіональному рівнях зумовлюється:

- впровадженням сучасних інформаційних технологій для підтримки інноваційної діяльності та новаційних методів ведення бізнесу, розробленням особливих систем роботи готельно-ресторанних об'єктів, які сприяють розширенню їх функціональних послуг, зокрема задіяння мультимедійних технологій у вигляді різноаспектних довідників, рекламних буклетів, електронних каталогів інноваційних пропозицій, в тому числі й в мережі Інтернет. Зазначений інноваційний підхід дає можливість споживачам туристичних послуг швидко i якісно орієнтуватися у багатогранній туристичній інформаційній системі і вибору найбільш прийнятної споживачу;

- освоєнням нових туристичних ресурсів пов'язаних 3 природно-ландшафтними особливостями територій, сприятливою екологічною ситуацією, дотриманням постулатів суспільного розвитку на основі інноваційної складової;

- застосуванням сучасних видів організаційно-управлінської діяльності із врахуванням управлінських технологій, як низки управлінських засобів впливу з метою досягнення результативності окреслених цілей функціонування туристичних об' єктів, до яких передусім відносяться достовірність інформаційних даних про забезпечення ефективної діяльності туристичної організації чи фірми, формування системи контролю з метою виявлення проблемних питань розвитку тощо;

- пошуку нових ринків з метою просування послуг і товарів у сфері туризму тощо.

Висновки. Отже, узагальнення інформаційних даних дає можливість стверджувати, що в сучасних складних умовах господарювання і ведення бізнесу зумовлюється необхідність впровадження інноваційних підходів до забезпечення розвитку сфери туризму, доцільним є застосування прийому дифузії інновацій як вагомої складової розвитку досліджуваної сфери, саме в умовах мінливості вибагливих вимог споживачів туристичних послуг і туристичного продуктів. Подальші дослідження стосуватимуться реалізації інноваційних проектів у сфері еко-, агро- і зеленого туризму.

\section{Список використаних джерел:}

1. Данилишин Б.М., Дорогунцов С.І. , Міщенко В.С., Коваль Я.В., Новоторов О.С., Паламарчук М. М. Природноресурсний потенціал сталого розвитку України. Київ : РВПС, 1999. 716 с.

2.ДП „Хустське лісодослідне господарство”/Офіційний сайт. URL: https://zakarpatlis.gov.ua/portfolio-item/dp-hustskelisove-doslidne-hospodarstvo/

3.Закарпаття - санаторії та туризм : статист. зб./ Головне управління статистики у Закарпатській області; за ред. Г.Д.Гринник. Ужгород, 2018. $15 \mathrm{c}$.

4.Кравців В. С., Свдокименко В. К., Габрель М.М. Рекреаційна політика Карпатського регіону. Чернівці : Прут, 1995. $68 \mathrm{c}$.

5.Любіцева О.O. Методика розробки турів: поняття про туристичний продукт URL: http://tourlib.net/books_ukr/lubiceva_mrt1.htm

6.Офіційний сайт Хустської районної державної адміністрації. URL: https://khust-rda.gov.ua

7.Сайт туристичної Хустщини. URL: https://tourinform.org.ua/tag/hustskyj-rajon-uk/

8.Статистичний щорічник Закарпаття за 2017 рік/ Головне управління статистики у Закарпатській області; за ред. Г. Д. Гриник. Ужгород, 2013. $511 \mathrm{c.}$

9.Туритстичні перспективи Хустського району Закарпаття. URL: http://www.zakarpattyatourism.info/product_info.php?1 Рецензент д.е.н., професор Ковальська Л.Л. 